\title{
Meta
}

Journal des traducteurs

Translators' Journal

\section{ZHANG, J. H. and K. P. CHEN (2005): Renowned Translators: Their Theory and Practice (in Chinese), Shanghai, Fudan University Press, 346 p.}

\section{Jianzhong Xu}

Volume 53, numéro 4, décembre 2008

URI : https://id.erudit.org/iderudit/019663ar

DOI : https://doi.org/10.7202/019663ar

Aller au sommaire du numéro

Éditeur(s)

Les Presses de l'Université de Montréal

ISSN

0026-0452 (imprimé)

1492-1421 (numérique)

Découvrir la revue

Citer ce compte rendu

$\mathrm{Xu}$, J. (2008). Compte rendu de [ZHANG, J. H. and K. P. CHEN (2005): Renowned Translators: Their Theory and Practice (in Chinese), Shanghai, Fudan University Press, 346 p.] Meta, 53(4), 935-936. https://doi.org/10.7202/019663ar d'utilisation que vous pouvez consulter en ligne.

https://apropos.erudit.org/fr/usagers/politique-dutilisation/ 
tive, readers' response and responsibility, lost generation and generalization, rationality or reality, and style as a style), ten categories about theories of translation Buddhist sutra, key points on translation criticism of Hongloumeng, or The Dream of Red Mansion, a classical Chinese novel. The appendices not only make the writing style of the book quite different from others, the content more substantial, interesting, but also make the book more Chinese and more readable.

Translation criticism is relatively backward in China. There is a great need for translation critics, who are vastly under-represented compared to the great many persons engaged in theoretical research, personnel fostering and translation practice. In China, the translation critic is seen as someone who is unable to do translation. Likewise, the reviewer is seen as someone who cannot do research work. Hence, translation critics and book reviewers are looked down upon. This is deleterious to Translation Studies because translation criticism is a major part of it. It is high time to reverse the trend. Wang's monograph is one effective step towards this goal.

Wang is well-qualified to have written this book given his background as M.A. both in psychology and literature, as a Chinese calligrapher, a lover of traditional Chinese nature paintings of mountains, water, as a writer, poet, translation practitioner, college teacher of English-Chinese and Chinese-English translation, the head of a Translation Studies center, and his familiarity with the nature of translation.

In sum, the book under review is excellent although it only discusses one aspect of literary translation and ignores the other, variable translation such as edited translation, selective translation, partial translation, and simplified translation. It is a very good initiative and an important contribution to Translation Studies.

JIANZHONG XU

Tianjin University of Technology, Tianjin, China

Zhang, J. H. and K. P. Chen (2005): Renowned Translators: Their Theory and Practice (in Chinese), Shanghai, Fudan University Press, 346 p.

As the title implies, quite different from theoretical study, Renowned Translators: Their Theory and Practice is the introduction to 14 modern and contemporary translators' life experiences, their views on translation and the appreciation of their translations. They are Yan Fu (1854-1921), Hu Shi (1891-1962), Lin Yutang (1895-1976), Zhu Shenghao (1912-1944), Qian Zhongshu (1910-1998), Fu Lei (1908-1966), Yang Xianyi (1915-), Gladys Yang (19191999), Yu Guangzhong (1928-), Xu Yuanchong (1921-), Wang Zuoliang (1916-1995), Wang Xiancai (1934-), David Hawkes (1923-), Sidney Shapiro (1915-). From the translators we know that the book's coverage - not only Chinese but also their international colleagues - has contributed enormously in disseminating Chinese culture to the world.

The book demonstrates the translators' dedication and devotion to this worthy cause. Wang Xiancai, "the greatest sci-tech translator in China" as the book suggests, translates Cecil Textbook of Medicine four times according to successive editions from 1957 to 1985 (when the translated version was first published). His unfortunate experience is due to various reasons such as the political movements in China when he suffered political persecution and imprisonment. Even in prison he persisted in his translation work. The published translation of Cecil Textbook of Medicine amounts to 4,700,000 words.

Some translators in China can do foreign language(s)-Chinese translation, and vice versa. $\mathrm{Xu}$ Yuanchong is a case in point. He can translate not only literary works from English and French into Chinese, but also classical and contemporary Chinese poems and dramas into English and French. By 2003 he had published 60 works, both at home and 
abroad. Translators are generally only capable of doing one-way translation, but Xu translates both ways.

There is a story of the wonderful cooperation between the couple, Yang Xianyi (Chinese) and Gladys Yang (British), and the only one in China's translation history. Their life-long cooperation has produced over 40 works translated from Chinese to English even though their approach differs, the former preferring literal translation and the latter liberal translation. Their success proves a Chinese saying "Perfect marriage arranged by Heaven."

What is different about this book is its emphasis not only on literary translation but also on sci-tech translation (Wang Xiancai's medical translation), which indicates that scitech translation is now gaining importance in China.

The book's translators have two things in common. One is that they are entirely absorbed in translation practice, and pay little attention to translation theory. They just say a few words about translation, touching only the surface matter of translation. Such views comprise "faithfulness, expressiveness and elegance," "to be alike in spirit and form," and "to reach the acme of perfection," which indicates the shortcomings of translation studies in China - not systematic. The other is that they are versatile, adept at languages and other knowledge. Hu Shi is an expert in philosophy, archaeology and literature, and Wang Xiancai is a doctor and writer. As translators, they possess outstanding talents, and the ordinary translator cannot hold a candle to them

All Chinese translators' views on translation derive from their practice, and fall within Yan Fu's criteria of "faithfulness, expressiveness and elegance," which deserves reconsideration and ferreting out the essence of them, on the basis of which, we can explore the orientation of translation studies in China. In present-day China, Western theories are very popular, but the Chinese one(s) are neglected, which hinders the development of translation studies in China. In the authors' opinion, translation studies in China should focus principally on the Chinese language and culture, with the foreign ones as supplements.

In sum, these translators' achievements and experience, their unique views on translation greatly inspire us later generations. We can also perceive the charm from the comparison of the masterpieces of the original and the translated version with the authors' appreciation and appraisal. However, some theories in the book such as "faithfulness, expressiveness and elegance," "to be alike in spirit and form," and "to reach the acme of perfection" are, in my opinion, not theories but some views on translation.

JIANZHONG XU

Tianjin University of Technology, Tianjin, China 